УдК: 355:616-036.21(497.11)

DOI: https://doi.org/10.18485/fb_covid19.2020.ch14

\title{
МЕСТО И УЛОГА ВОЈСКЕ У ОДГОВОРУ НА ПАНДЕМИЈУ
}

\author{
проф. др Зоран Јефтић 1 \\ проф. др Горан Мандић²
}

Апстракт: Савремени безбедносни изазови посматрани кроз климатске промене, глобално отопљавање, раст светске популације и урбанизацију, повећану мобилност становништва, еколошке проблеме и низак ниво јавног здравља у великом броју земаља света - стварају повољан амбијент за појаву и ширење преносивих болести, као и развијање епидемије и пандемије. Упркос технолошком развоју и медицинским протоколима везаним за епидемије и пандемије, стављање у други план ризика од заразних преносивих болести показао је да превентивне мере које се предузимају у савременом свету нису биле довољне да спрече пандемију старог/новог вируса ковида 19. Суочено са новим изазовима и претњама, постмодерно друштво условљава промену мисија војске са класичних ка нетрадиционалним мисијама очувања и изградње мира и њене употребе на сопственој територија као допуна цивилним ресурсима у случајевима различитих кризних ситуација. Промене које су настале у међународном и националном окружењу, нова безбедносна парадигма и достигнути степен реформе система одбране и Војске Србије стално постављају питање каква је војска потребна Републици Србији. Нова безбедносна реалност условљава већ степен међузависности цивилних и војних актера. Стога је и неизоставно питање шта су инфективне болести пандемијског карактера донеле и где се сместила Војска као ослонац националне унутрашње и спољне безбедности. Пандемија ковида 19 захватила је становништво Републике Србије, што је условило да се у одговору

\footnotetext{
1 Универзитет у Београду, Факултет безбедности; e-mail: jefticz@ymail.com. Чланак је резултат рада на пројекту Министарства просвете, науке и технолошког развоја Републике Србије, на основу потписаног Уговора о реализацији и финансирању НИО у 2020. години, као и Плана рада НИО Факултета безбедности за 2020. годину Погледи и ставови изнети у чланку одражавају лични став аутора, а не институције у којој је запослен.

2 Универзитет у Београду, Факултет безбедности; e-mail: goran.mandic@fb.bg.ac.rs Погледи и ставови изнети у чланку одражавају лични став аутора, а не институције у којој је запослен.
} 
на ту врсту безбедносног ризика активно укључи и Војска Србије са својом организацијом, статусом, угледом и ресурсима. Због великих расположивих ресурса у здравственој области као посебно питање отвара се тема адекватне употребе војних ресурса и њена припрема за будуће значајније ангажовање у случају нових епидемија на простору Републике Србије.

Кључне речи: Заразне болести, епидемија, пандемија, војска, мисије војске, ковид 19.

\section{УвоД}

Још крајем прошлога века традиционално схватање безбедности и одбране, па и позиција војске у њему постала су преуска. Глобална кретања изнедрила су велики број нових, нетрадиционалних безбедносних ризика, и у безбедносном простору потврдили старе, али и модификоване, безбедносно проблеме, од којих заразне болести заузимају веома високу позицију. Цикличне појаве пандемија, које су у последњих двадесет година донеле пет великих претњи - САРС, МЕРС; ебола, птичји грип и свињски грип и актуелна пандемија ковида 19 - биле су део стварности и у 21 веку. ${ }^{3}$ Ова врста ризика, са немогућношћу њеног потпуног контролисања, последица је пре свега климатских промена, глобализације, урбаних кретања, социјалноекономског контекста везаног за кризу, сиромаштва и мигрантских померања из области ендемских ризика. То се посебно односи на нове облике вируса, као што је случај са ковидом 19. Пракса је показала да национални, али и шири одговор на ову врсту ризика захтева ангажовање и потпуну координацију свих расположивих потенцијала на нивоу државе, али и у оквирима међународне сарадње.

Као неизоставан ресурс и подршка цивилним органима власти увек се препознаје и војска, посебно у оперативном одговору у случајевима појаве заразних болести епидемијског и пандемијског карактера. Сам концепт цивилно-војне сарадње, поиман као интеракција цивилних и војних актера у остваривању функције војске, у основи је њеног ангажовања у свим за војску законски делегираним мисијама. Увођењем у међународну праксу хуманитарног интервенционизма и промена улоге војске у мултинационалним операцијама, уз потребу решавања великог броја проблема који имају цивилна обележја (хуманитарна питања, обнова инфраструктуре, здравствено збрињавање, локална администрација) условило је теоријско уобличавање цивилно-војне сарадње и њено везивање пре свега за мировне мисије. Један број земаља, међу којим је и Србија, развио је и доктринарно уредио цивилно-војну сарадњу, као функцију војске инкорпорирану

3 Изјава за ВВС професора Метју Бејлис (Matthew Baylis) са Универзитета у Ливерпул. Видети у: Викторија Гил, „Корона вирус: Зашто Ковид-19 није последња пандемија“, $B B C$ News, 15 јун 2020, https://www.bbc.com/serbian/cyr/svet-52995436, 05/07/2020. 
у све три њене мисије. Као последица глобалних климатских промена улога и значај војске у подршци и помоћи цивилним органима у превенцији и супротстављању у ванредним ситуацијама све више добија на значају.

Рад се бави анализом цивилно-војне сарадње, местом и улогом војске и нужности њеног ангажовања у случају пандемије, са посебним освртом на војни медицински потенцијал. Као могући одговор излаже се концепт цивилно-војне сарадње, у склопу постмодерне војске 21. и актуелне пандемије ковида 19. Место Војске Србије у одговору на пандемију и ангажовање њених ресурса изнеће се као посебан пример из праксе, док ће медицински аспект пандемије бити обрађен у мери која је потребна за ову врсту рада.

\section{ИНСТИТУЦИОНАЛНИ ОКВИР АНГАЖОВАҢА ВОЈСКЕ У СЛУЧАЈЕВИМА МИРНОДОПСКИХ КАТАСТРОФА}

Суочено са новим изазовима и претњама, постмодерно друштво условљава и постмодерно позиционирање војске и промену у приоритетима њених мисија. То у новом добу подразумева организационе, структуралне и културолошке промене, али и отклон од класичних ка мисијама очувања и изградње мира, а још важније и њену употребу на сопственој територија, као допуна цивилним ресурсима у случајевима различитих кризних ситуација. Нова безбедносна реалност условљава већи степен међузависности цивилних и војних актера и њихову синергију у супротстављању мирнодопским катастрофама. ${ }^{5}$

Ове промене резултују феноменом који можемо назвати постмодерни парадокс повезаност и удаљеност оружаних снага од друштва. И док је прво узроковано мешањем унутрашњих и спољашњих безбедносних ризика и повећањем сарадње између војних и цивилних институција, други сегмент је проузрокован неизбежном професионализацијом војске и њеним преласком на међународне мисије. ${ }^{6}$

Друга половина двадесетог века у оквиру армија развијеног света, теоријски, доктринарно и институционално изродила је цивилно-војну сарадњу као функцију војске у оквиру међународних организација и на националном нивоу. Полазећи од појмовног одређења и семантичке анализе цивилно-војна сарадња се може одредити као координирана заједничка активност цивилних и војних актера ради пружања подршке реализацији војне мисије. У ширем контексту тај

\footnotetext{
4 У овоме раду под мирнодопским катастрофама подразумеваћемо стање у коме је проглашена ванредно стање или ванредна ситуација.

5 Погледати шире о постмодерном поимању војске: Charles C. Moskos, John Allen Williams, and David R. Segal, (eds.), The Postmodern Military: Armed Forces After the Cold War, Oxford University Press, New York, 2000.

${ }^{6}$ Charles C. Moskos, John Allen Williams, and David R. Segal (eds.), The Postmodern Military: Armed Forces After the Cold War, Oxford University Press, New York, 2000, p. 11.
} 
облик сарадње означава успостављање контакта и спровођење активности између наведених актера уз међусобну подршку, са намером постизања заједничког циља уз обострану добит и корист. ${ }^{7}$

Уједињене нације као приоритет цивилно-војне сарадње виде у хуманитарно раду кроз све могуће облике сарадње и активности цивилних и војних актера у оквиру циља и мандата УН ${ }^{8}$. НАТО, са изузетком Турске, поима употребу војске кроз концепт цивилино-војне сарадње кроз мултинационалне операције и дефинише га као „координација и сарадња, у подршци мисији, између команданта НАТО-а и цивила, укључујући домаће становништво и локалну власт, као и међународне, државне и невладине организације и институције“.9 Европска унија, слично НАТОу, дефинише цивилно-војну сарадњу у случају операција управљање кризама, природно ван територије земаља ЕУ. ${ }^{10}$ Национална решења држава чланица НАТО и ЕУ углавном инклинирају чланству у наведеним организацијама и детаљније су уређена националном стратегијом и законодавством. ${ }^{11}$

Прихватљиву понуду за улогу војске у оквиру граница земље дао је Ентони Форстер (Anthony Forster) у свом раду „Оружане снаге и друштво у Европи“. Аутор је на основу искуства европских земаља дао приказ могућег ангажовања војске у оквиру сопствене територије, искључујући одбрану од спољашњег напада и профилисао кроз три задатка. Први који се односи на подршку у одржању реда и закона у случајевима када цивилна власт процени да је безбедност државе угрожена и када захтева употребу војске (military aid to the civil power - MACP ). Други обухвата успостављање „неопходних служби у име владе, када оне нису више способне да обављају своју функцију и када је нужно потребна војна помоћ владиним телима (military assistance to government departments - MAGD). Tpeћa област односи се на ангажовање војске у помоћи цивилним органима власти у случају природних и других несрећа (military aid to the civil Community - MACC). ${ }^{12}$

Џон Кларк (Johan L. Klark), амерички аутор, у свом раду „Улога европских војних и безбедносних снага у 21. веку“, даје значајнију улогу војске у примени силе примерено цивилним потребама, а мање њено ангажовање као испомоћи у

7 Зоран Јефтић, Миленко Лаловић, Цивилно-војна сарадња - стварност и потреба, Медија центар одбрана, Београд, 2011, стр. 15.

8 "UN CM-coord.Field Handbook (2018)", United Nations Office for the Coordination of Humanitarian Affairs, October 2018.

9 “NATO Civil-Military Cooperation Doctrine (2003)", NATO, July 2003.

10 "EU Concept for Civil-Military Co-operation (CIMIC) for EU-led Military Operations (2008)", Council of the European Union - Military Staff, 2008.

11 Изузетак се може сматрати Турска која посебну пажњу поклања употребе војске на сопственој територији као облик подршке цивилним властима у случајевима мирнодобских природник и техничких катастрофа.

12 Zoran Jeftić, Goran Mandić, „Use of Armed Forces In Emergency Situations - Migrant crises”, 3rd International Conference on Human Security Belgrade, May 2017, University of Belgrade Faculty of Security Studies, Human Security Research Center, 2017, p. 247. 
хуманитарним пословима13. Иако има сличну поделу као и Ентони Форстер о потенцијалној употреби војске у миру, посебно истиче да у оквиру могућег ангажовања војске (велики штрајкови, спортски догађаји, нарушавања реда и закона, заштита живота и имовине) задаци постављени војсци од стране цивилних органа власти могу бити ван прописане надлежности војске. ${ }^{14}$ То уједно покреће дебату око оптимизације цивилно-војних односа, кроз демократску контролу и употребу војске у законски уређеним условима.

Конкретна решења у државно-правној пракси појединих земаља су слична и усмерена пре свега на цивилно-војну сарадњу у оквиру мировних мисија, док се њено ангажовање на домаћој територији различито третира. Република Србија је следствено стварним потребама, али и уважавајући међународне стандарде развила и институционално уредила сопствени концепт цивилно-војне сарадње, који у практицирању у случајевима природних катастрофа показује добре резултате. За разлику од већине развијених земаља, а на основу реалне процене безбедносних изазова, ризика и претњи, расположивих ресурса Министарства одбране, као и исказаних потреба за њено ангажовање - уобличена је и нормативно уређена цивилно-војна сарадња у оквирима све три мисије Војске Србије. 15 Значај њеног постојања показала је и потреба ангажовања ресурса Војске у великим природним непогодама (екстремним временским условима и поплавама), а показује и данас кроз активну партиципацију војног здравства и логистичких капацитета Војске у одговору на актуелну пандемију ковида 19.

\section{ДОМАТА УПОТРЕБА ВОЈСКЕ СРБИЈЕ У СЛУЧАЈЕВИМА МИРНОДОПСКИХ КАТАСТРОФА}

Уставом из 2006. године у одељком 6. поново се васпоставља Војска Србије са свим прерогативима које имају све савремене војске 21. века.16 Њено место, улогу, мисије и задатке у условима ванредног стања и ванредних ситуација у основи су уређени стратешким и законским документима. Основни проблем стратешког оквира везан је за непостојања системски уређених стратегијских докумената. Република Србија није развила кровну, националну стратегију, из које би произашле стратегије за све остале области, укључујући и безбедност и одбрану. У Републици Србији у промету је преко 100 стратегија које би се могле назвати

13 Jack L. Klark, “What Roles and Missions for Europe's Military and Security Forces in the 21st Century", Marshall Center Papers, No. 7, 2005, p. 18.

${ }^{14}$ Defense assistance to civil authority - DACA; Defense support to civilian law enforcement authority - DSCLEA; Defense assistance to civil disturbances - DACDIS.

15 У стратегијским документима одбране највећег броја земаља, најчешће се помињу три мисије војске: одбрана земеље, учешће у мировним мисијама и помоћ цивилним органима у случају несрећа.

16 „Устав Републике Србије“, Службени гласник PC, бр. 98/2006, Београд, 10. новембар 2006. 
државним и о чијем хијерархијском односу нису заузети посебни ставови. Стога, у оквиру сектора безбедности у целини постоји сагласје око Стратегије националне безбедности, као носећег документа, из кога природно происходе и сва остала стратегијска документа, па и она која се односе на одбрану и војску ${ }^{17}$.

Стратегија националне безбедности у оквиру безбедносних изазова, ризика и претњи Републици Србији, поред оних који се директно односе на војску, истиче и епидемије и пандемије заразних болести, елементарне непогоде и техничкотехнолошке несреће и последице климатских промена, као изазове ризика и претњи који у својој ескалацији могу захтевати и употребу ресурса војске. Стратегија националне безбедности генерише и стратегију усмерену на област мирнодопских катастрофа које могу резултирати проглашењем ванредног стања или ванредне ситуације.

Стратегија одбране Републике Србије задржава елементарне непогоде и техничко-технолошке несреће као безбедносни изазов препознат са становишта одбране, и то потврђује у поглављу 2. наведеног документа.18 Истовремено у поглављу 4.2. посебно се истиче потребу за ефикасном заштитом и спасавање становништва у миру, ванредном стању и рату, где се неизоставно мора препознати и улога Војске. У поглављу 6.3. дефинисане су и мисије Војске Србије (BC): одбрана Републике Србије од оружаног угрожавања споља; учешће у изградњи и очувању мира у региону и свету и подршка цивилним властима у супротстављању претњама безбедности. ${ }^{19}$ За реализацију мисија ВС има сагласје да обједини све учеснике у борбеним операцијама и надлежна је за командовање свим снагама које изводе борбена дејства у ванредном стању и рату, на основу

17 „Стратегија националне безбедности Републике Србије“, Службени гласник РС, број 94/2019, 27. децембар 2019.

18 „Стратегија одбране Републике Србије“, Службени гласник РС, број 94/2019, 27. децембар 2019.

Стратегија одбране Републике Србије, поглавље 2. став осам: „Елементарне непогоде, техничко-технолошке несреће, као и радиолошка, хемијска и биолошка контаминација настала као последица ратних дејстава и техничко-технолошких несрећа представљају сталну безбедносну претњу за Републику Србију, њено становништво, материјална и културна добра и животну средину. Негативне последице ових појава могу да захвате и угрозе територије суседних држава, а могу се, исто тако, са територија суседних држава проширити на Републику Србију и угрозити њену територију и становништво“.

19 Одбрана Републике Србије од оружаног угрожавања споља реализује се одвраћањем од оружаног угрожавања, одбраном територије и одбраном ваздушног простора.

Учешће у изградњи и очувању мира у региону и свету реализује се учешћем у међународној војној сарадњи и у мултинационалним операцијама.

Подршка цивилним властима у супротстављању претњама безбедности реализује се кроз помоћ цивилним властима у супротстављању тероризму, сепаратизму, организованом криминалу и другим облицима унутрашњег угрожавања безбедности, као и путем помоћи цивилним властима у случају природних непогода и техничкотехнолошких и других несрећа. 
закона, а у складу с доктрином Војске Србије. Посебно је значајно да су творци стратегије препознали значај и место Војске у подршци цивилним властима у супротстављању претњама безбедности, што се у пракси у највећем броју случајева усмерава ка последицама природних катастрофа.

Ова област садржана је и у оквирима Националне стратегије заштите и спасавања у ванредним ситуацијама ${ }^{20}$ („Службени гласник РС“, бр. 86/2011 од 18.11.2011. године). Наведена стратегија, као основни стратегијски документ, који се односи на ванредне ситуације, први је документ оваквог облика и садржаја на нашим просторима. Ова Стратегије наведена је и као једна од осам актуелних стратегија чији је носилац Министарство унутрашњих послова РС21. Садржајно је подигла на виши ниво превентивне мере и интерресорну сарадњу, па и ангажовање ресурса војске, кроз захтеве за континуирану процену ризика, као основу за превентивне, али и оперативне мера одговора на ванредне ситуације. Стратегија је, како је у њој назначено, поред Стратегије националне безбедности, узела у обзир Националну стратегију одрживог развоја, законску регулативу Републике Србије и највећим делом се ускладила са глобалним стратешким ставовима за смањење ризика усвојеним у оквиру за деловање из Хјого документа 2005-2015, као и у документу Уједињених нација који се односи на миленијумске циљеве развоја.

Основни законски документ који регулише систем смањења ризика од катастрофа и управљање ванредним ситуацијама, па и ангажовање војних ресурса јесте Закон о смањењу ризика од катастрофа и управљању ванредним ситуација. 22 Наведени закон у оквиру снага система смањења ризика од катастрофа препознаје и Војску Србије, члан 13, став 3. Посебним чланом 26. дефинисано је да у условима када друге снаге и средстава система нису довољна за заштиту и спасавање људи и материјалних добара од последица катастрофа, на захтев Републичког штаба за ванредне ситуације ангажују се снаге и средства Министарства одбране и Војске Србије, осим у ратном и ванредном стању. Ангажованим јединицама Војске Србије командују њихове надлежне старешине, али у складу са препорукама Штаба за ванредне ситуације који руководи и координира заштитом и спасавањем. Поред наведеног овим законом се може у случајевима када улазимо у стање у коме су „ризици и претње или настале последице по становништво, животну средину и материјална и културна добра таквог обима и интензитета да њихов настанак или последице није могуће спречити или отклонити редовним деловањем надлежних органа и служби, због чега је за њихово ублажавање и отклањање неопходно, употребити посебне мере,

20 „Национална стратегија заштите и спасавања у ванредним ситуацијама (2011)“, Службени гласник РС, бр. 86/2011, Београд, 18.11.2011.

21 „Стратегија развоја Министарства унутрашњих послова за период 2018-2023. године (2018)“, Службени гласник РС, бр. 78, Београд, 19. октобар 2018.

22 „Закон о смањењу ризика од катастрофа и управљању ванредним ситуацијама (2018)“, Службени гласник РC, бр 87/2018, Београд, 13. новембар 2018. 
снаге и средства уз појачан режим рада“.23 Овако дефинисан појам се односи и на пандемију или епидемију заразних болести, као што је ковид 19, с обзиром на то да се сматрају природном појавом већих размера које могу да угрозе безбедност, живот и здравље већег броја људи и тиме спадају у елементарне непогоде, односно катастрофе због којих може бити проглашена ванредна ситуација.

Законска регулатива која покрива област одбране подржава опште ставове о ангажовању Војске у случајевима великих катастрофа, тако да се у Закону о одбрани Републике Србије 24 дефинише ванредно стање као стање јавне опасности у којем је угрожен опстанак државе или грађана, а последица је војних или невојних изазова, ризика и претњи безбедности. ${ }^{25}$ Став 11 . истог члана препознаје невојне изазове ризике и претње међу којима су наведене и елементарне непогоде, техничко-технолошке и друге несреће и опасности за које се заједно са војним изазовима, ризицима и претњама ради и усваја процена. Употреба ВС у њеној трећој мисији регулисана је и Законом о одбрани, члан 41, који дефинише да у случају природних и других несрећа већих размера у којима су на одређеној територији угрожени живот и здравље људи и животиња и материјална добра јединице Војске Србије на захтев органа надлежних за заштиту и спасавање људи и материјалних добара могу се ангажовати на пружању помоћи становништву у складу с посебним законом. Још прецизније у члану 43. даје се право начелнику генералштаба односно старешинама надлежних команди да на основу посебног овлашћења председника Републике, а ради заштите и спасавања људи, материјалних и културних добара од елементарних непогода, техничкотехнолошких несрећа и катастрофа, последица тероризма и других већих несрећа - може наредити мере спровођења приправности и употребу делова Војске Србије ради отклањања штетних последица које могу настати невојним претњама безбедности. У поглављу 7. новог Закона о одбрани од члана 77. до члана 80. дате су одреднице о цивилној заштити, са јасним опредељењем да цивилна заштита у ванредном и ратном стању функционише као део система одбране.

Законом о Војсци Србије у поглављу које говори о надлежностима и месту Војске Србије експлицитно је наведено да председник Републике или министар одбране по овлашћењу председника Републике може одлучити да Војска Србије надлежном државном органу, односно организацији, органу аутономних покрајина и органу јединица локалне самоуправе, на њихов захтев, пружи помоћ

23 Ибид. Члан 2, став 7.

24 „Закон о одбрани Републике Србије (2018)“ Службени гласник РС, бр. 36/2018, Београд, 10. мај 2018, члан 2. став 4 а

25 Ванредно стање у складу са законом проглашава Народна скупштина (члан 9. став 1.), ако није у могућности да се састане одлуку о проглашењу ванредног стања доносе заједно председник Републике, председник Народне скупштине и председник Владе, под истим условима као и Народна скупштина (члан 10. став три). 
ради заштите живота и безбедности људи и имовине, заштите животне средине или из других разлога утврђених законом. ${ }^{26}$

Наведена законска решења проткана су и кроз доктринарна документа Војске Србије, а пре свега кроз Доктрину војске и Доктрину цивилно-војне сарадње. Посебно је значајно да је паралелно са законским уређењем система за одговор на катастрофе Република Србија у оквиру организационе структуре Војске Србије као спону између цивилних институција надлежних за катастрофе и ванредне ситуације и ресурса одбране Војске развијан сопствени оригинални концепт цивилно-војне сарадње. Даља анализа у овоме раду односиће се на њену трећу мисију Војске и употребу у времену проглашења пандемије ковида 19 у Републици Србији.

\section{ВОЈСКА СРБИЈЕ У ОДГОВОРУ НА ПАНДЕМИЈУ КОВИДА 19}

Климатске промене, глобално отопљавање, неприхватљив ниво урбанизације, раст светске популације и значајно смањење природних ресурса погодују појави инфективних болести са пандемијским потенцијалом. Уједно глобална кретања и повећана мобилност људи подстиче ширење епидемија које постају све опасније због брзине преношења и броја заражених. Друштвене и економске кризе у виду ратова и различитих сукоба погодују ширењу епидемија, које је у наведеним ситуацијама скоро немогуће контролисати.

Заборављене болести као што су колера и велике богиње још увек озбиљно прете појединим земљама и регионима. Долазак новог коронавируса у облику ковида 19 још увек је са нејасним ресурсом и непредвидивим трајањем, али и са једном непобитном чињеницом - да је због високог процента вирулентности по први пут у познатој историји захватио практично све земље света и отворио ново поглавље у борби са инфективним болестима. У поређењу са другим инфективним болестима корона 19 је једина имала у периоду од марта до јуна 2020. веома висок број оболелих и преминулих на свим континентима. ${ }^{27}$

Јавне здравствене установе које чине: дом здравља, апотека, болница, завод, завод за јавно здравље, клиника, институт, клиничко-болнички центар и клинички центар, у Републици Србији обављају здравствену делатност на примарном, секундарном и терцијарном нивоу и имају своју законом устројену мрежу по целој

26 „Закон о Војсци Србије (2019)“, Службени гласник РС, бр. 94/2019, Београд, 27. децембар 2019, члан 2.

27 "2020. Human development perspectives - COVID-19 and Human Development: Assessing the Crisis, Envisioning the Recovery", United Nations Development Programme, New York, 2020, available at:

http://hdr.undp.org/sites/default/files/covid-19_and_human_development_0.pdf, 14/07/2020, p.4. 
територији државе 28 . Овај здравствени ресурс Републике Србије преузео је носећу улогу борбе против ковида 19, укључивши и све остале расположиве капацитете, пре свих оне којима располаже Министарство одбране и Војска Србије.

\section{Расположиви ресурси Министарства одбране и Војска Србије}

МO и ВC представља најобученији и најорганизованији и релативно опремљени део друштва, са широким дијапазоном способности и што је за доносиоце одлука најважније, расположивим у кратком временском периоду. Здравствени капацитети Министарства одбране су респектабилни (око 5000 запослених) и представљају значајан ресурс на који се држава може ослонити у оваквим ситуацијама. Као посебност и специфичан ресурс за ситуацију пандемије јесу и капацитети Војномедицинске академије, која у оквиру интегралног објекта заузима површину од 180.000 метара квадратних и годишње прегледа 600.000 људи, хоспитализује 30.000 , обави око 20.000 хируршких интервенција и око 3.000.000 милиона лабораторијских и дијагностичких процедура. Њени постељни капацитети износе 1200 кревета. Војномедицинска академија има 27 клиника и 17 института са моћним дијагностичко-поликлиничким центром. ${ }^{29}$ Посебно је значајно што у оквиру BMA функционише Центар за контролу тровања, који представља националну референтну установу и важан ослонац државе у свим акцидентним ситуацијама и који уз мобилне токсиколошке лабораторије може у неким сегментима покривати и део који се односи на биолошке агенсе и вршити хоспитализацију пацијената. Поред наведеног, војни здравствени систем у оквиру своје надлежности има и Војну болницу Ниш, Војномедицински центар Нови Сад, Центар војномедицинских установа Београд, са укупно 1644 болничких кревета, већи број здравствених установа примарног нивоа заштите, што уз капацитете којима располаже трупни војни санитет чини незаобилазан ресурс за одговор на било који здравствени проблем, укључујући и епидемије и пандемије.

Војска Србије у оквиру своје организације поседује и посебне јединице Атомскобиолошко-хемијске одбране. Постојањем и развојем јединог националног, али и регионалног центра за усавршавање кадрова АБХО, створени су услови за обуку, заједничко међународно ангажовање тимова, изучавање националних мобилних тимова за обуку и инструктора, као и подршку цивилним властима у земљи и државама региона и Европе.

Поред наведенога војска располаже и значајним логистичким капацитетима за превенцију и санирање последица заразних болести, као и оперативним снагама (војна полиција, специјалне јединице), које могу помоћи полицијским снагама у

28 „Уредба о плану мера здравствене заштите (2005)“, Службени гласник PC, број 107/05, Београд, 2. децембар 2005.

29 Зоран Јефтић, Елизабета Ристановић и др, „Здравље више од злата Универзијада 2009 Health More Than Gold Univewrsiacde 2009“, Медија центар Одбрана, Београд, 2011, стр. 50-51. 
одржавању потребног нивоа безбедности. Војска се опрема, обучава и развија највећим делом за сопствене потребе, а може се употребити и по захтеву цивилних органа власти. С обзиром на то да се ради о ресурсима који су ограничени, системски одговор на наведени ризик условљава интерресорну сарадњу и координацију.

\section{Анализа употребе Војске}

Увођењем ванредног стања 16. марта и позиционирањем војске као једног од актера у санирању пандемије отворила се јавна полемика о целисходности доношења овакве одлуке и прескакању редоследа, који би требао отпочети са ванредном ситуацијом. Као што је наведено, Законом о смањењу ризика од катастрофа и управљању ванредним ситуацијама дато је право да Министарство унутрашњих послова и Републички штаб за ванредне ситуације (РШВС) буду носећи актери управљања системом и да се ресурси Војске Србије на захтев РШВС ангажују у ситуацијама када снаге и средстава редовних цивилних служби нису довољне ${ }^{30}$. Ванредно стање је уставна категорија и представља супституцију некадашње одреднице непосредне ратне опасности, и регулисана је и Законом о одбрани. Проглашењем ванредног стања, за које се може устврдити да је стање које се пре свега односи на спољну војну претњу, систем одбране и Војска као његов носећи део преузимају главну руководну улогу са председником у улози врховног команданта.

У том од проглашења пандемије за ковид 19 понашање политичких актера извршне власти било је између „ситуације и стања“. Влада РС је формирала свој кризни штаб који је у себе уградио већ постојеће стручно тело РШВС за епидемије, а Војска је добила задатке који би се у највећем делу могли уоквирити у област ванредних ситуација. Доминантна улога председника Републике била је видљива и у складу са проглашеним ванредним стањем. С обзиром на то да циљ овога рада није бављење анализом и давањем одговора на питање: шта је узроковало проглашење ванредног стања, а не ванредне ситуације (стварна потреба, одлагање избора, потреба за јавном промоцијом), даће се кратак осврт на активности које је спроводила Војска Србије у периоду од 16. марта до 7. маја 2020. године.

30 „Закон о смањењу ризика од катастрофа и управљању ванредним ситуацијама (2018)“, Службени гласник РС, бр 87/2018, Београд, 13. новембар 2018. Члан 26. „У условима када друге снаге и средства система нису довољне за заштиту и спасавање људи, материјалних и других добара од последица катастрофа, на захтев Републичког штаба за ванредне ситуације, Министарство одбране обезбеђује учешће својих организационих јединица, команди, јединица и установа Војске Србије за пружање помоћи у заштити и спасавању, у складу са законом, осим у ратном и ванредном стању. Када у заштити и спасавању учествују јединице Војске Србије, њима командују њихове надлежне старешине, у складу са закључцима и препорукама штаба за ванредне ситуације који руководи и координира заштитом и спасавањем.“ 
Ресурси Министарства одбране и Војске Србије били су активирани од само појаве вируса на простору Републике Србије. ${ }^{31}$ Тиме се и у пракси ставио на проверу концепт цивилно-војне сарадње Војске Србије. Почетно ангажовање усмерено је на војноздравствене установе и припаднике MO и ВC, са циљем одржавања нивоа оперативних способности и обављања редовних дужности. Усложњавањем ситуације почетком марта месеца и порастом броја заражених и хоспитализованих лица наметнула се потреба за проглашењем ванредне ситуације, која је у надлежности Владе Републике Србије. Одлука се темељила на чињеници да стање јавне опасности, у овом случају заразне болести, угрожава опстанак државе или грађана и да сет мера које омогућава увођење ванредне ситуације није довољан, тако да се могла отворити и тема увођења ванредног стања. С обзиром на то да је Народна скупштина распуштена, једина могућност да се прогласи ванредно стање остала је на заједничкој одлуци председника Народне скупштине Србије, председника Републике Србије и председнице Владе Србије. На основу процене безбедносне претње која се односила на ковид 19, а коју је сачинило МО - Управа за војно здравство, 16. марта 2020. проглашено је ванредно стање на територији читаве земље.

Ова одлука отворила је могућност за увођење мера у којима се могла препознати значајнија улога војске у функцији помоћи цивилном здравственом сектору. Као што је и најављено, у оквирима спровођење треће мисије Војска Србије је имала два кључна задатка уоквирена са пружањем подршке цивилним органима власти и одржавањем потребног нивоа оперативних и функционалних способности. На основу одлуке о увођењу ванредног стања за целу територију Србије на нивоу Министарства одбране и Генералштаба Војске Србије донете су одлуке и наређења из својих надлежности које се односе на трећу мисију Војске Србије о ангажовању њених припадника на пружању подршке цивилним властима у спречавању ширења вирусне инфекције. Прво захтеви за ангажовање Војске усмерени су на обезбеђење и контролу јавних објеката, главних болница, граничних прелаза, као и обезбеђење прихватних центара и центара за азил и надзор над изолацијом простора и људи.

У делу полицијских задатака безбедности и јавног реда Војска Србије је преузела обезбеђивање 51 здравствене установе у 24 града и општине; 20 прихватних центара и центара за азил; 153 установе социјалне заштите у 50 градова и испомоћ у обезбеђењу привремено затворених граничних прелаза за друмски саобраћај и отворених граничним прелазима према Хрватској, Мађарској, Бугарској и Северној Македонији, где је пружана помоћ граничној полицији и

31 Број ангажованих лица на дневном нивоу 1500, уз обављање редовних обавеза, то је представљало значајно напрезање људских ресурса мирнодобског састава Војске Србије. 
санитарној инспекцији. ${ }^{32}$ у сегменту ангажовања војних снага на овим задацима објективно се може поставити питање потребе присуства професионалних војника са дугим цевима за обезбеђење здравствених установа и установа социјалне заштите, осим ако су процене тог тренутка захтевале растерећење полицијских снага и њену немогућност да одговори традиционалној улози.

У оквиру здравствене подршке Војска Србије се ангажовала на: припреми, опремању и руковођењу са девет привремених ковид болница у пет градова, са укупно постављених 5.122 кревета; на надзору 18 објеката за наше држављане пристигле из иностранства; на формирању ковид болнице у Војномедицинском центру „Карабурма“; на преузимању цивилних пацијената у Војномедицинску академију, Војну болницу Ниш и Војну болницу Нови Сад. ${ }^{33}$

Идеја око проглашења Војномедицинске академије као централне ковид болнице није могла бити реализована, те су се и сви остали делегирани болнички капацитети војног здравства преточили у болничке ресурсе Републике Србије и вршили прихват свих пацијената из цивилних ковид болница.

Снаге АБХО ангажоване су на 60 локација за потребе дезинфекције. Употреба јединица АБХО у овом случају само за деконтаминацију отвара посебно питање њеног значаја и места у спречавању и одговору на заразне болести. Компонента ове службе која се бави и биолошким оружјем је запостављена у истраживачком раду и у пракси.

У оквиру логистичке подршке Војска Србије је ангажовала 2200 возила са укупно пређених 900.000 километара и превезених 43.000 лица и 29.000 тона терета. ${ }^{34}$ Логистички капацитет Војске Србије показује потребу за поновним промишљањем и у правцу подизања сопствених способности за потребе све три мисије војске, але не ван тог оквира. Јасно дефинисана улога војске у трећој мисији, одређена као подршка цивилним властима у супротстављању претњама безбедности у миру, укључујући природне катастрофе којима припадају и пандемије - опредељује војску и као институционално додатни ресурс. То истовремено показује мањкавост и нерационалност логистичке употребе

32 На територији Републике Србије, у време проглашења пандемије, затекло се 8.000 миграната, те је било нужно контролисати њихово кретање и боравак. На основу захтеав који је упућен Министарству одбране, Војска Србије је преузела обавезу обезбеђења и контроле и ограничење кретања у 20. прихватних центара и центара за азил. Ова мера је била нужна обзиром на категорију миграната који су углавном транзитног карактера и могу бити потенцијални преносиоци заразне болести. Оправданост ове мере показала је и чињеница да је било неколико озбиљних инцидената и покушај организованог и масовног напуштања центара.

33 Обзиром да из техничких разлога Војно медицинска академија није могла постати ковид болница она је заједно са, Војном болницом Ниш и Нови Сад постала место за за терцијални ниво лечење и цивилних пацијената

34 Подаци преузети из „Посебан прилог магазина Министарства одбране и Војске Србије 'Одбрана““, Одбрана, бр. 336/јуни, 2020, стр 5-10. 
капацитета државе и локалне самоуправе у таквим ситуацијама. У пракси се дешава да војска доноси своје шаторе, а да их локална самоуправа може обезбедити, да се користе војна превозна средства, а да локал располаже са далеко већим капацитетима, да је спремање хране у свакој локалној самоуправи рационалније од развијања тог типа логистичке подршке од стране војске. Војска јесте расположив ресурс, али поред поруке да је руководство државе свесно озбиљности проблема и да војска нуди умирујућу поруку да ће се проблеми санирати, најчешће код цивилних структура постоје нереална очекивања да та државна институција може надоместити све недостатке постојећег система за превенцију и одговор на претњу, у овом случају пандемију.

Посебна дилема која се појавила односи се на снаге цивилне заштите и њихову употребу у ванредном стању. Систем цивилне заштите у потпуности и веома детаљно је уређена Законом о смањењу ризика од катастрофа и управљању ванредним ситуацијама, док је Законом о одбрани цивилна заштита део система одбране у ванредном и ратном стању. Следствено наведеном, снаге и средства цивилне заштите требале су бити ангажоване у време пандемије и координисане од стране Министарства одбране. То би у пракси омогућило да се оперативне снаге Војске релаксирају у делу постављања и припрема привремених болница, шаторских комплекса, организације логистичког снабдевања, па чак и делу контроле и обезбеђења објеката. Одговор на питање: зашто се то није десило лежи у недовољној спремности МО да преузме ту законом предвиђену обавезу, али и у потреби ревитализације тог веома значајног сегмента система заштите и спасавања.

Ангажовање војног здравства и Војске Србије у другом таласу ковида 19 у току јула и августа месеца било је усмерено на припрему пољске војне болнице у Новом Пазару у циљу ефикасније борбе против епидемије коронавируса, која у том граду има озбиљне размере. За кратко време формирана је пољска војна болница капацитета 110 кревета, са могућношћу проширења до 170 кревета, у којој су лечени лакше и средње тешко оболели пацијенти. Лечење за све пацијенте из региона Новог Пазара, Сјенице и Тутина ангажовано је око 40 лекара и медицинских техничара, који пружају помоћ особљу Дома здравља Нови Пазар, Тутин и Сјеница.

Активирана је ковид болница у ВМЦ „Карабурма“, у којој ради више од 220 медицинских радника и у којој је смештено 117 пацијената. Војска Србије је обезбеђивала, поставила и снабдевала особљем, заједно са представницима Министарства здравља, привремену болницу у београдској Арени за пријем пацијената оболелих од ковида 19 са лакшом клиничком сликом. Војномедицинска академија је поново преузела улогу опште болнице за пацијенте из целе Србије, а своје ресурсе ставили су на располагање Војна болница у Новом Саду и Војна болница у Нишу. 


\section{Предлози за унапређење стања}

Заразне болести које имају капацитет да покрену масовне епидемије и пандемије представљају значајне безбедносне ризике савременог света Ова врста опасности транспарентно је препозната у стратегијама водећих земаља света, међународним безбедносним организацијама, али и националним стратегијама, укључујући и Србију.

Актуелна ситуација и ангажовање Војске у време пандемије показали су да систем заштите и спасавања у нормативној сфери има задовољавајућу форму, али да још увек у функционалном делу захтева доградњу, како би се избегле импровизације и систем у потпуности заокружио. С обзиром на то да су припадници војног здравства, а посебно њен руководећи кадар, униформисана лица са посебном дисциплином, одговорношћу, начином рада и размишљања, њихово прилагођавање ванредним условима рада и додатном напрезању није ништа ново, те је било за очекивати и њихово веће присуство у управљању и раду кризних штабовима на свим нивоима организовања. Посебно као добра порука становништву, које традиционално има поверења у Војску и њене способности.

Да би будућа употреба ресурса Војске у случајевима појаве епидемије и пандемије била ефективнија и ефикаснија било у ванредним ситуацијама или ванредном стању, потребно је предузети следеће:

- усклађивања оперативних процедура за употребу Војске, у трећој мисији, са стварним потребама;

- уградња у планове обуке, садржаје које захтева ангажовање у цивилном окружењу;

- усклађивања планова употребе са Сектором за ванредне ситуације;

- остваривање вишег ниво комуникације и размене информација команди ВС и штабова за ванредне ситуације на свим нивоима организовања;

- занављања потребне опреме и обуке на истом;

- унапређење националних способности заштите од заразних болести;

- већи степен укључивања војног здравства у руковођење и рад кризних штабова;

- значајнија улога Штабова за ванредне ситуације;

- одрживост система војног здравства, са тежиштем на управљању материјалним и људским ресурсима и стабилном финансирању;

- школовање и усавршавање потребног кадра на свим нивоима;

- опремање система војног здравства савременим средствима и побољшање услова за рад санитетског и ветеринарског кадра;

- сусретно планирање и постизање потребног нивоа сарадње са цивилним здравственим системом.

Као један од могућих облика ефикасније употребе војних снага на задацима цивилне заштите у ванредним ситуацијама може да буде и концепт флексибилне организације војних јединица, који би задовољили овакве захтеве и могли да одговара потребама заједничког учешћа цивилних и војних структура у кризама 
изазваних елементарним непогодама, еколошким катастрофама, епидемијама и пандемијама на националном и регионалном нивоу. 35

Посебно је значајно да је због својих ресурса АБХО центар у Крушевцу проглашен регионалним и да се у њему интензивно организују обуке из ове области и да се на ВМА налазе респектабилни ресурси. Те чињенице дају за право да се ова посебност Министарства одбране и Војске Србије препозна као национални ресурс и развије до нивоа потребног за значајније учешће у борби против заразних болести.

\section{ЗАКЉУЧАК}

Током целокупне историје ништа није убило толико људи колико биолошки агенси који узрокују заразне болести, те се и садашњи развој човечанства мора сучелити са наведеном чињеницом. Глобално отопљавање, климатске промене, мигрантска кретања, али и појава пандемија и претње јавном здрављу показали су у практично свим земљама света потребу за стратегијским промишљањем и одбрамбеним планирањем. То у основи подразумева развијање оптималног модела цивилно-војне сарадње, базираног пре свега на чињеници да највећи резервни, оперативни ресурси за превенцију и одговор на појаву заразних болести пандемског типа налази се у оквиру Министарства одбране и Војске.

Мирнодопски здравствени капацитети које војска сваке земље поседује, логистички потенцијали, а посебно специфични ресурси у оквиру атомскобиолошке и хемијске одбране дају значајан потенцијал да кроз цивилно-војну сарадњу учествују у свим облицима помоћи цивилном здравственом систему. У циљу достизања задовољавајућег нивоа спремности и отпорности нужна је успостава интерресорне сарадње и умрежавање војних и цивилних капацитета усмерених на развијање способности јавног здравственог система и других релевантних институција за превенцију и умањење последица потенцијалних заразних болести.

Синергија која постоји у Републици Србији, профилисана пре свега у оквиру капацитета којима располаже Министарство одбране и Војска Србије, даје могућност одговора на појаву епидемија и пандемија у националном и регионалном простору. Актуелна ситуација и присуство вируса ковида 19, као и искуства из досадашње употребе ресурса Министарства одбране и Војске Србије у санирању последица заразне болести, дају реалну слику значаја њиховог ангажовања, укупних капацитета, али и слабости и лимита. Све уочене недостатке

35 Погледати шире у: Momcilo Milinovic, Željko Ivaniš, Ivica Lj. Djordjevic, Zoran Jeftic, "Interoperable Role of National Defense in the Protection of Regional Critical Infrastructure" Security and Crises management Theory and Practices, $2^{\text {nd }}$ International Scientific Professional Conference Security for Future, Obrenovac, 2016, ISBN 978-868069800-01-4, pp. 164-171. 
треба реално сагледати и у оквиру развоја свеукупних националних ресурса пронаћи оптимално место и за Министарство одбране и Војску Србије. Истовремено је запажено да је потребно у оквиру војноздравственог система успоставити бољу контролу постојања и активности биолошких агенаса и подржати је развојем и обуком потребног медицинског кадра.

Војна организација и начин функционисања су оптимални амбијент за развијање мобилних лабораторија са одговарајућом опремом и кадром. Уједно би било потребно да се у планове и програме обуке припадника Војске уграде адекватни садржаји који се односе на место и њихову посебну улогу у одговору на наведени ризик, уз чување постојећих капацитета војноздравственог система за медицинско збрињавање и хоспитализацију оболелих. Све ово мора бити подржано мултидисциплинарним приступом за изградњу капацитета за процену ризика од појаве заразних болести и брзи одговор свим расположивим ресурсима на националном и на регионалном нивоу.

\section{ЛИТЕРАТУРА}

- "2020 Human development perspectives - COVID-19 and Human Development: Assessing the Crisis, Envisioning the Recovery", United Nations Development Programme, New York, 2020, available at: http://hdr.undp.org/sites/default/files/covid-19_and_human_development_0.pdf, $14 / 07 / 2020$.

- "EU Concept for Civil-Military Co-operation (CIMIC) for EU-led Military Operations (2008)", Council of the European Union - Military Staff, 2008.

- "NATO Civil-Military Cooperation Doctrine (2003)", NATO, July 2003.

- "UN CM-coord.Field Handbook (2018)", United Nations Office for the Coordination of Humanitarian Affairs, October 2018.

- „Закон о Војсци Србије (2019)“, Службени гласник РС, бр. 94/2019, Београд, 27. децембар 2019.

- „Закон о одбрани Републике Србије (2018)“ Службени гласник РС, бр. 36/2018, Београд, 10. мај 2018.

- „Закон о смањењу ризика од катастрофа и управљању ванредним ситуацијама (2018)“, Службени гласник РС, бр 87/2018, Београд, 13. новембар 2018.

- „Посебан прилог магазина Министарства одбране и Војске Србије 'Одбрана““, Одбрана, бр. 336/јун 2020.

- „Стратегија националне безбедности Републике Србије“, Службени гласник РС, број 94/2019, 27. децембар 2019.

- „Стратегија одбране Републике Србије“, Службени гласник РС, број 94/2019, 27. децембар 2019.

- „Стратегија развоја Министарства унутрашњих послова за период 2018-2023. године (2018)“, Службени гласник РС, бр. 78, Београд, 19. Октобар 2018. 
- „Уредба о плану мера здравствене заштите (2005)“, Службени гласник РС, број 107/05, Београд, 2. децембар 2005.

- „Устав Републике Србије“, Службени гласник РС, бр. 98/2006, Београд, 10. новембар 2006.

- Jeftić, Zoran, and Mandić, Goran. „Use of Armed Forces in Emergency Situations Migrant Crises". 3rd International Conference on Human Security Belgrade, May 2017, University of Belgrade - Faculty of Security Studies Human Research Center 2017.

- Klark, Jack L. "What Roles and Missions for Europe's Military and Security Forces in the 21st Century", Marshall Center Papers, No. 7, 2005.

- Milinovic, Momcilo, Ivaniš, Željko, Djordjevic, Ivica, Jeftic, Zoran. "Interoperable Role of National Defense in the Protection of Regional Critical Infrastructure" Security and Crises management Theory and Practices, 2nd International Scientific Professional Conference \Security for Future, Obrenovac, 2016, ISBN 978-868069800-01-4.

- Moskos, Charles C., Williams, John Allen, and Segal, David R. (eds.). The Postmodern Military: Armed Forces After the Cold War. Oxford University Press, New York, 2000.

- Гил, Викторија. "Корона вирус: Зашто Ковид-19 није последња пандемија“, ВВС News, 15 јун 2020, https://www.bbc.com/serbian/cyr/svet-52995436, 05/07/2020.

- Јефтић Зоран, Ристановић, Елизабета и сар. Здравље више од злата Универзијада 2009 - Health More Than Gold Universiade 2009. Медија центар Одбрана, Београд, 2011.

- Јефтић, Зоран, Лаловић, Миленко. Цивилно-војна сарадња ج стварност и потреба. Медија центар одбрана, Београд, 2011.

\section{ROLE OF THE ARMED FORCES IN THE PANDEMIC RESPONSE}

Abstract: Contemporary security challenges, seen as climate changes, global warming, growth of the population and urbanization, increased mobility of the population, ecological problems and low levels of public health in vast majority of countries of the world, create a favorable ambient for the appearance and spread of infectious diseases, as well as epidemics and pandemics. Despite technological advancement and medical protocols connected with epidemics and pandemics, sidelining the risks of infectious diseases showed that preventive measures taken in the world today were not enough to prevent the pandemic of the new-old COVID-19 virus. Faced with new challenges and threats, postmodern society is causing a change of missions of the armed forces, from the classical towards non-traditional missions of protecting the peace and peacebuilding, as well as its use on one`s own territory in addition to civil resources during different crisis situations. Changes created in the international and national environment, new security paradigm and reached level of defence system and Serbian Armed Forces reform constantly raise the question what kind of armed forces does the Republic of Serbia need. New 
security reality is causing a greater degree of interdependence between civilian and military actors. Therefore, the questions of what did infections diseases of pandemic character bring and where did the Armed Forces position themselves (as the fulcrum of national security) were raised. COVID-19 pandemic has impacted the society of Republic of Serbia which caused that the response tu this kind of a security risk Armed Forces of Serbia need to actively contribute with its organizational capacities, reputation and resources. Because of large available resources in the health sector an additional question is rased, relating to the adequate use of military resources and its preparations for future, larger involvement in cases of new epidemics within the Republic of Serbia.

Key words: infectious diseases, epidemic, pandemic, military, missions of the military, COVID-19 